\title{
Conditioned aversion to minimize Ferula communis intake by orphaned lambs
}

\author{
SERGE Y. LANDAU, EZRA BEN-MOSHE, ANAT EGBER, ALAN SHLOSBERG, MICHEL BELLAICHE, AND \\ AVI PEREVOLOTSKY
}

Authors Landau and Perevolotsky are range scientists, and Ben-Moshe is agricultural research technician, Department of Natural Resources, Institute of Field and Garden Crops, Agricultural Research Organization, The Volcani Center, P.O. Box 6, Bet Dagan 50250, Israel; Egber is field advisor, Sheep and Goats Department, Extension Service, Ministry of Agriculture, P.O. Box 7054, Haqirya Tel Aviv 61070, Israel; Shlosberg and Bellaiche are toxicologists, Kimron Veterinary Institute, P.O. Box 12, Bet Dagan 50250, Israel.

\begin{abstract}
The circum-Mediterranean perennial Ferula communis $\mathbf{L}$. (giant fennel) has anticoagulant constituents. Mortality from poisoning can affect $5 \%$ of the sheep grazed in infested areas and most casualties are ewe-lambs at the onset of the grazing season. In intensive sheep production systems, ewe-lambs are "orphaned", artificially reared, and have no opportunity to acquire safe dietary habits by imitating their mothers. The aim of the present study was to evaluate the intake of $F$. communis in such lambs and to assess the potential of using conditioned aversion as a managerial tool to decrease the frequency of $F$. communis poisoning. Six lambs weighing approximately $28 \mathrm{~kg}$ were averted to $F$. communis using 2 administrations of $4 \mathrm{~g} \mathrm{LiCl}$ in aqueous solution, given immediately after a meal of $F$. communis; 6 similar lambs served as unaverted controls. The intake of $F$. communis and the persistence of aversion were assessed over 7 observation days using a simulation of an infested field where freshly cut bunches of $F$. communis were tied to stakes at 10-m intervals in ryegrass (Lolium multiflorum Lam.) paddocks at the late vegetative stage. Averted lambs grazed separately from unaverted counterparts. Time spent by lambs foraging on $F$. communis was in the range of $0-0.015 \mathrm{~min} /$ hour (not significantly different from nil) in averted, and $0.15-0.24 \mathrm{~min} / \mathrm{hour}$ in unaverted lambs, respectively $(P=0.002)$. Consequently, the rate of disappearance of $F$. communis was greater when grazing was by unaverted than averted lambs $(0.29$ and $0.15 \mathrm{~g} / \mathrm{min}, P=$ $0.01)$. The aversion persisted for 25 days after the $\mathrm{LiCl}$ treatment, at which time observations were discontinued. Assuming that the amount of $F$. communis that disappeared is close to actual intake by lambs, intake by unaverted lambs was high enough to endanger the lambs, whereas averted lambs consumed safe amounts of the poisonous plant. It is concluded that conditioned aversion has the potential to alleviate the problem of $F$. communis poisoning in orphaned ewe-lambs.
\end{abstract}

Key Words: Sheep grazing; poisonous plants; conditioned food aversion

Corresponding author: Dr. S. Landau; fax: 972-3-9669642; E-mail: vclandau@volcani.agri.gov.il

We thank Dr. Menahem Zachs and the Jewish National Fund for partial funding of this project. Contribution from the Agricultural Research Organization, Institute of Field and Garden Crops, Bet Dagan, Israel, No. 114/98.

Manuscript accepted 8 Nov. 1998.

\section{Resumen}

La especie perenne circunmediterranea Ferula communis $\mathbf{L}$. ("Giant fennel") tiene constituyentes anticoagulantes. La mortalidad por envenenamiento con esta especie puede afectar hasta el 5\% de los borregos apacentando áreas infestadas, la mayoría de las bajas son corderos hembras y ocurren al final de la estación de apacentamiento. En sistemas de producción intensiva de ovinos, los corderos hembras son destetadas y alimentados artificialmente por lo que no tienen la oportunidad de adquirir hábitos de alimentación segura a través de imitar a sus madres. El objetivo de este estudio fue evaluar el consumo de $\boldsymbol{F}$. communis en corderos destetados y el potencial de uso de la aversión condicionada como una herramienta de manejo para disminuir la frecuencia de envenenamiento con $F$. communis. Seis corderos de aproximadamente $28 \mathrm{~kg}$ de peso fueron condicionados adversamente a $F$. communis mediante 2 administraciones de $4 \mathrm{~g}$ de $\mathrm{LiCl}$ en solución acuosa suministrada inmediatamente después de una comida de $F$. communis, seis corderos similares sin aversión fueron utilizados como control. El consumo de $\boldsymbol{F}$. communis y la persistencia de la aversión a esta especie fueron evaluados durante 7 días mediante la simulación de un terreno infestado. La simulación se realizó en una pradera de ryegrass (Lolium multiflorum Lam.) donde manojos recién cortados de $F$. communis se ataron a estacas con una separación de $10 \mathrm{~m}$, la pradera estaba a finales de la etapa vegetativa. Los corderos con aversión apacentaron separadamente de los corderos sin aversión. El tiempo utilizado en apacentar $F$. communis estuvo en el rango de 0 a $0.015 \mathrm{~min} / \mathrm{hr}$ (Sin diferencia significativa de nil) para los corderos con aversión y de 0.15 a $0.24 \mathrm{~min} / \mathrm{hr}$ para los corderos sin aversión $(P=0.002)$. Consecuentemente, la tasa de desaparición de $F$. communis fue mayor con el apacentamiento de corderos sin aversión que con aversión $(0.29$ y $0.15 \mathrm{~g} / \mathrm{min}, P=0.01)$. La aversión persistió por 25 días después del tratamiento con LiCL, tiempo en que se suspendió la observación de los animales. Asumiendo que la cantidad de $\boldsymbol{F}$. communis que desapareció es cercana al consumo actual por los corderos, el consumo de los corderos sin aversión fue suficientemente alto para ponerlos en peligro, mientras que los corderos con aversión consumieron cantidades de esta planta tóxica que no fueron peligrosas. Se concluye que la aversión condicionada tiene potencial para disminuir el problema de envenenamiento de corderos hembra por $F$. communis. 
The circum-Mediterranean perennial Ferula communis L. (giant fennel) is known to contain anticoagulant constituents in healthy, fresh plant material (Shlosberg and Egyed 1985). Mortality can affect $5 \%$ of the sheep grazed on infested areas. Most casualties are ewelambs at the onset of the grazing season within 30 days of being turned out, probably because at that time $F$. communis is prominent and lush whereas alternative herbaceous vegetation is still scarce (Egber et al., unpublished data). In the intensive lamb meat production system practised in Israel, ewe-lambs are separated from their mothers at birth (i.e., "orphaned"), raised artificially using an automatic milk dispenser, and weaned to solid food at 25-30 days of age and $12-15 \mathrm{~kg}$ body weight (BW). While learning from adults is considered of major importance in acquiring safe dietary habits (Thorallsdotir et al. 1990, Provenza et al. 1993), there is little opportunity for adults to influence the dietary habits of young animals in this type of production system. Also, autumn-born lambs can be first turned to green pasture when 3-months old but do not interact socially with adult ewes during the first grazing season (Egber unpublished data). Herbicidal eradication of $F$. communis was practised in the past, but it is now considered ecologically unsound. In regions where $F$. communis is widespread, shepherds will defer grazing and alternate grazing in infested and non-infested paddocks to prevent poisoning, which results in incomplete exploitation of pasture (Shlosberg and Egyed 1985). While $F$. communis is toxic when fed to lambs at $2.5 \mathrm{~g} / \mathrm{kg} \mathrm{BW} / \mathrm{day}$, it causes no disturbance in blood clotting at $1.0 \mathrm{~g} / \mathrm{kg}$ BW/day (Shlosberg and Egyed 1985). Toxicity of $F$. communis decreases somewhat after the plant has flowered (Egyed et al. 1981). There is no quantitative information available on $F$. communis intake by weaned lambs grazed on infested range.

It appears that no post-ingestive discomfort is felt when sheep feed on $F$. communis (Shlosberg and Egyed 1985) and the plant is abundant and palatable. These are favorable conditions for the implementation of conditioned food aversion (CFA) against $F$. communis, e.g. artificial build-up of temporal contiguity between ingestion of the plant and artificially induced post-ingestive pain, in order to elicit rejection by lambs at later encounters (Ralphs 1992). Lithium chloride $(\mathrm{LiCl})$ has been used frequently as a malaise-inducing agent to establish a CFA procedure, due to its relative safety and taste analogy with sodium chloride (du Toit et al. 1991). The procedure has been shown to induce persistent CFA to Cercocarpus montanus and Amelanchier alnifolia in sheep by Burritt and Provenza (1989), to Oxytropis sericea (Ralphs et al. 1997) and Delphinium barbeyi (Ralphs 1997) in cattle, and to Pinus brutia in goat kids (Nolan and Nastis 1996). Procedures for conditioned food aversion (CFA) have been implemented in lambs accompanying their mothers (Provenza et al. 1993), in 3-month old weaned lambs (Burritt and Provenza 1990, du Toit et al. 1991) and in adult sheep (Provenza et al. 1993). We recently developed a procedure to establish CFA to $F$. communis in orphaned weaned lambs in individual cages. While testing the procedure in the field, we found that the efficacy of CFA to $F$. communis interacts with pasture availability (Egber et al., unpublished data). Others have shown that social facilitation causes sheep to extinguish aversions (Burritt and Provenza 1989, Provenza and Burritt 1991, Provenza et al. 1993). Therefore, the assessment of the efficacy of CFA and, in particular, the evaluation of its persistence, must be carried out under strictly controlled field conditions, where averted and nonaverted lambs graze separately in similar plots, before any extrapolation to commercial range conditions.

This study was aimed at: (i) quantifying the intake of $F$. communis by weaned lambs at the onset of their first grazing season; and (ii) assessing the value of creating conditioned food aversion to $F$. communis as a potential aid to improve range utilization by sheep in infested regions under controlled field conditions.

\section{Materials and Methods}

The experiments were carried out at Kibbutz Har'el in the Judean Hills of Israel $\left(31.7^{\circ} \mathrm{N}, 35.0^{\circ} \mathrm{E}\right)$, where rangelands are heavily infested with $F$. communis. Twelve weaned "orphaned" German Landschaff Merino ewe-lambs, aged 80 days and weighing approximately $27.8 \mathrm{~kg}(\mathrm{SE}=0.90)$, were housed in individual cages $(1.7 \times 1.7 \mathrm{~m})$ on a dirt floor in a roofed building. Six lambs served as averted group and 6 lambs served as controls. During the 2 weeks before attempting to establish aversions to $F$. communis was implemented, lambs were fed daily a basic diet comprising $300 \mathrm{~g}$ of a commercial starter concentrate (18\% crude protein, Ambar, Hadera, Israel) and $300 \mathrm{~g}$ of chopped oat hay containing $8.1 \%$ crude protein $(\mathrm{CP})$, $68.5 \%$ neutral detergent fiber (NDF) and $42.1 \%$ acid detergent fiber (ADF) on a dry matter (DM) basis. Fresh water was available ad lib. As lambs were reluctant to consume $F$. communis foliage when it was offered in the trough, the plant was tied in bunches of approximately $200 \mathrm{~g}$ which were positioned vertically to the cage frames with metal clamps, so as to simulate the natural position of plants, as described by Meuret (1988) and Provenza et al. (1993). On March 27, when the average daily intake of $F$. communis foliage reached approximately $40 \mathrm{~g}(\mathrm{SE}=9 \mathrm{~g})$ fresh, a conditioned food aversion (CFA) protocol was carried out by administering $4 \mathrm{~g} \mathrm{LiCl}$ in aqueous solution, immediately after $F$. communis was provided, independent of $F$. communis intake, using a de-worming gun (day 0). Sodium chloride was administered to the control lambs. No $F$. communis was provided on March 28. On March 29, F. communis foliage was presented to lambs, followed by a second administration of $4 \mathrm{~g} \mathrm{LiCl}$. Following the second $\mathrm{LiCl}$ administration, individual cages were dismantled, lambs were managed as 1 flock and turned to a late vegetative Italian ryegrass (Lolium multiflorum Lam.) paddock of 0.30 ha which had been sown in November and grazed occasionally from the beginning of January. It was divided into 2 similar plots, each of 0.15 ha. Lambs were accustomed to grazing in both plots as 1 group from day 4 to day 7 after the first $\mathrm{LiCl}$ treatment. Provision of the basic diet of oat hay was discontinued in order to enhance intake at pasture. Standing biomass and pasture quality were estimated by clipping five, $0.25 \times 0.25 \mathrm{~m}$ quadrats in each plot. Samples were dried in a forced air oven at $60^{\circ} \mathrm{C}$ for 48 hours and then weighed. Initial standing biomass averaged 4,740 $(\mathrm{SE}=320)$ and 6,040 $(\mathrm{SE}=350) \mathrm{kg} / \mathrm{ha}$ in plots $\mathrm{A}$ and $\mathrm{B}$, respectively; $\mathrm{CP}, \mathrm{ADF}, \mathrm{NDF}$ and ash content were similar in both plots and 
averaged $10.8 \%, 30.3 \%, 51.2 \%$ and $13.3 \%$, respectively. The standing biomass throughout the experiment was similar in the two fields (Fig. 1).

An artificial simulation of a pasture infested with $F$. communis was constructed as follows: Nine, 1-m-high iron stakes were sunk $30 \mathrm{~cm}$ into the ground and their position was defined using a letter and a number. The distance between stakes was approximately 10 $\mathrm{m}$, which is approximately the distance between $F$. communis plants in infested range. The lambs were grazed alternately on the 2 plots; averted and non-averted lambs grazed separately, and allocation of plots was switched every day. Grazing behavior on the $F$. communisinfested paddock was observed on 7 occasions from 4 April to 22 April. On these days, freshly cut bunches of $F$. communis weighing approximately 350 $\mathrm{g}$ fresh were tied tightly to the base of each stake, to mimic the natural appearance of the plant. Three bunches were weighed and laid out of lambs' reach for evaluation of water loss. Grazing bouts lasted $180 \mathrm{~min}$., apart from 1 bout of $120 \mathrm{~min}$. on 1 very hot day. At the end of each grazing bout the $F$. communis bunches were gathered, weighed and weight change was corrected for water loss. If uneaten residues of $F$. communis were found on the ground near stakes, their weight was subtracted from the initial weight of a bunch before disappearance of $F$. communis was calculated. Lambs were identified by numbers painted on both sides of the body. Two observers were allocated to each plot, and observations were made from a distance of 2 to $5 \mathrm{~m}$. The presence of observers had no detectable effect on the grazing activity and social relationships of these "orphaned" lambs, because they were accustomed to being handled from birth. Every encounter of a lamb with $F$. communis was documented. When an animal started to forage on $F$. communis (an event we term a "grazing encounter"), the observer recorded the lamb number and the exact time. At the end of an encounter, the time was recorded again. Persistence of conditioned food aversion (CFA) was tested until day 25 after establishment of the CFA. On that date $F$. communis began to flower, and $F$. communis is attractive and toxic mainly before flowering (Egyed et al. 1981).

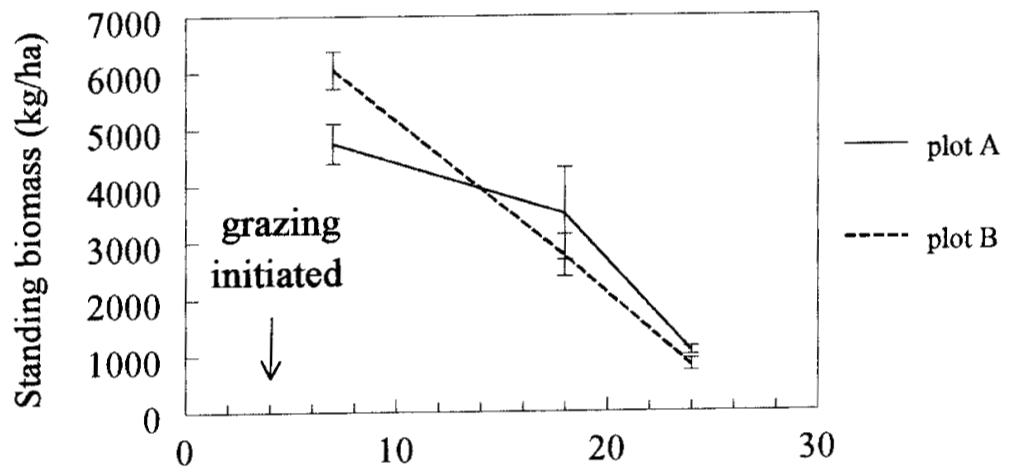

Days from first $\mathrm{LiCl}$ administration

Fig. 1. Standing biomass (kg /ha) of plots A and B throughout the experiment.

The effects of the aversion procedure on the intake of $F$. communis were evaluated by analyses of variance using a repeated measures procedure with lambwithin- treatment as the error term (SAS 1985). The weight change of F. communis bunches was analyzed using a bi-factorial procedure with CFA (yes/no) and plot (A/B) as main effects and their interaction. The effect of the position of the bunch on the number of encounters and the intake of $F$. communis was analyzed separately for each plot, using a bi-factorial procedure with CFA (yes/no) and position of bunch as main effects and their interaction.

\section{Results and Discussion}

No difference ( $\mathrm{P}=0.15$, Fig. 2a) was noted in the frequency of grazing encounters to $F$. communis in lambs averted or not averted to the plant but significant "plot" $(\mathrm{P}=0.01)$ and "lamb" $(\mathrm{P}=0.03)$ effects were noted for the frequency of grazing encounters $(\mathrm{P}=0.01)$ : some lambs grazed $F$. communis more frequently than others and plot B had $50 \%$ more grazing encounters to $F$. communis than plot $\mathrm{A}$. The average time spent by a lamb foraging on $F$. сотmunis ranged from 0 to $0.015 \mathrm{~min} / \mathrm{hour}$ (not significantly different from nil) in averted, and $0.15-0.24 \mathrm{~min} /$ hour in unaverted lambs, more than 10 -fold higher in the latter $(\mathrm{P}=0.002$, Fig. $2 \mathrm{~b})$. A strong $(\mathrm{P}=0.008)$ "lamb" effect on time spent foraging on $F$. communis was found, implying that some lambs consumed much more $F$. communis than others. This finding is in agreement with the description by Shlosberg and Egyed (1985) of lambs that "were assertively aggressive in their desire to receive their daily portion".

Overall, no plot effect were observed for time spent foraging on $F$. communis $(\mathrm{P}=0.32)$, but a stake $\times$ aversion treatment interaction tended to be significant in plot $\mathrm{B}(\mathrm{P}=0.06)$.

The aversion to $F$. communis, when assessed according to time spent foraging on $F$. communis, seemed to persist throughout the experiment (Fig. 2b). The location of $F$. communis bunches did not affect the frequency of visits and time spent foraging on them in plot A.

The rate of disappearance of $F$. communis was $0.218 \mathrm{~g}$ fresh/min/lamb. It was approximately double when grazed by non-averted, compared with averted, lambs $(0.29$ and $0.15 \mathrm{~g} / \mathrm{min}, \mathrm{P}=0.01)$. When disappearance was analyzed in a model which included aversion, plot, plot $x$ aversion and date, the effect of aversion was significant $(\mathrm{P}=0.008)$ and aversion $\mathrm{x}$ plot tended to be significant $(\mathrm{P}=0.10)$. Rate of disappearance tended to be affected by stake position in plot B: $0.19 \mathrm{~g} / \mathrm{min}$ for stakes A1-A2-A3, located along the fence between the 2 plots, compared with $0.13 \mathrm{~g} / \mathrm{min}$ from other stakes $(\mathrm{P}=0.07)$; a similar trend was found in plot A: $0.17 \mathrm{~g} / \mathrm{min}$ for stakes $\mathrm{C} 1-\mathrm{C} 2-\mathrm{C} 3$, also located along the fence between the 2 plots, compared with $0.12 \mathrm{~g} / \mathrm{min}$ for other stakes $(\mathrm{P}=0.19)$. This finding can be interpreted as an outcome of lambs in the experimental groups to grazing as close as possible to mates of the other group. This strengthens our assumption that conditioned food aversion (CFA) had to be evaluated first with groups which were separated while grazing, because of the negative anticipated effects of unaverted controls on averted lambs 
(Burritt and Provenza 1989; Provenza and Burritt 1991).

The rate of $F$. communis disappearance $(0.218 \mathrm{~g} / \mathrm{min} / \mathrm{lamb})$ was comparable to the $1.0 \mathrm{~g} / \mathrm{min}$ found with 6 lambs in a previous trial (Egber et al., unpublished data). Assuming that most of the $F$. communis which disappeared was eventually eaten, it can be calculated that unaverted lambs consumed 17 $\mathrm{g} /$ hour, or approximately $70 \mathrm{~g}$ during a 4 hour grazing day. Although lambs spent only about $1 \mathrm{~min} /$ hour foraging on $F$. communis, the amount of $F$. communis presumably eaten was close to $2.5 \mathrm{~g} / \mathrm{kg}$ BW/day. Supposing lambs were continuously grazing the infested paddock, which was not the case in the present study, this amount would be enough to impair prothrombin time in lambs within 9 days, and to be lethal within 11 days (Shlosberg and Egyed 1985). In contrast, the amount of $F$. communis consumed by the averted lambs (35 g/day) was approximately $1 \mathrm{~g} / \mathrm{kg} \mathrm{BW} /$ day, an amount which did not produce noticeable toxic effects within 21 days, according to Shlosberg and Egyed (1985). Therefore, implementation of conditioned food aversion (CFA) to F. communis can be a viable management technique for ewe-lamb survival in $F$. communis-infested rangelands.

In addition, CFA to $F$. communis persisted for at least 25 days, which is approximately the period by which $F$. communis precedes the growth of most annual herbaceous plants. Therefore, CFA established in this critical period could alleviate the problem of $F$. communis poisoning in ewe-lambs. Poisoning in adult sheep is rare, however, visits to $F$. communis are common, which may negatively affect the grazing behavior of newly averted lambs. There-

Burritt, E.A. and F.D. Provenza. 1990. Food aversion learning in sheep: Persistence of conditioned aversions to palatable shrubs (Cercocarpus montanus and Amelanchier alnifolia). J. Anim. Sci. 68:1003-1007.

du Toit, J.T., F.D. Provenza and A.S. Nastis. 1991. Conditioned food aversions: How sick must a ruminant get before it detects toxicity in foods? Appl. Anim. Behav. Sci. 30:35-47.

Egyed, M.N., A. Shlosberg, V. Handji and E. Rapaport. 1981. Changes in prothrombin time in subclinical experimental Ferula communis poisoning in sheep. Refuah Veterinarith (Quaterly of the Israel Veterinary Medical Association) 38:128-135.

Meuret, M. 1988. Feasibility of in vivo digestibility trials with lactating goats browsing fresh leafy branches. Small Rumin. Res. 1: 273-190.

Nolan, T. and A. Nastis. 1996. Some aspects of the use of vegetation by grazing sheep and goats. pp.11-25. In: J.E. Lindberg, H.L. Gonda, and I. Leddin (eds.), Recent Advances in Small Ruminant Nutrition. CIHEAM/FAO/Institut Agronomique et Veterinaire Hassan II. CIHEAM Publications, Zaragoza, Spain.

Provenza, F.D. and E.A. Burritt. 1991. Socially-induced diet preference ameliorates conditioned food aversion in lambs. Appl. Anim. Behav. Sci. 31:229-236.

Provenza, F.D., J.L. Lynch and J.V. Nolan. 1993. The relative importance of mother and toxicosis in the selection of foods by lambs. J. Chem. Ecol. 19: 313-323.

Ralphs, M.H. 1992. Conditioned food aversion: Training livestock to avoid eating poisonous plants. J. Range Manage. 45:46-51.

fore, the potential social influence must be studied before the procedure can be used on a wide scale, to determine whether only young ewe-lambs, or the whole flock, should be subjected to the CFA procedure and whether the CFA procedure should be repeated every year. The number of animals to be averted and the necessary frequency of the procedure for each animal are issues that will strongly affect the economic viability of this management option impact because the CFA procedure is difficult and time-consuming.

\section{Literature Cited}

Burritt, E.A. and F.D. Provenza. 1989. Food aversion learning: Conditioning lambs to avoid a palatable shrub (Cercocarpus montanus). J. Anim. Sci. 67: 650-653.
Ralphs, M.H. 1997. Persistence of aversions to larkspur in naive and native cattle. J. Range Manage. 50:367-370.

Ralphs, M.H., D. Graham, M.L. Galyean and L.F. James. 1997. Creating aversions to locoweed in naive and familiar cattle. J. Range Manage. 50:361-366.

SAS 1985. SAS/STAT Guide for Personal Computers. Version 6. SAS Inst., Cary, N.C.

Shlosberg, A. and M.N. Egyed. 1985. Experimental Ferula communis (giant fennel) toxicosis in sheep. Zbl. Vet. Med. A. 32:778-784.

Thorhallsdottir, A.G., F.D. Provenza and D.F. Balph. 1990. Ability of lambs to learn about novel foods while observing or participating with social models. Appl. Anim. Behav. Sci. 25:25-33. 